Yüzüncü Yil Üniversitesi
Tarim Bilimleri Dergisi

Derleme Makalesi (Review Article)

\title{
Enzimatik Hidroliz Yöntemi Kullanılarak Balık İşleme Atıklarından Balık Protein Hidrolizatı Üretimi
}

\author{
Koray KORKMAZ ${ }^{* 1}$, Bahar TOKUR ${ }^{2}$, Yılmaz UÇAR ${ }^{3}$ \\ 1,2,30rdu Üniversitesi, Fatsa Deniz Bilimleri Fakültesi, Balıkçılık Teknolojisi Mühendisliği Bölümü, Ordu, \\ Türkiye \\ ${ }^{1}$ https://orcid.org/ 0000-0003-2940-6592 ${ }^{2}$ https://orcid.org/ 0000-0002-6770-6652 ${ }^{3}$ https://orcid.org/0000-0002-7087-5801 \\ *Sorumlu yazar e-posta: koraykorkmazodu@gmail.com
}

\section{Makale Bilgileri}

Geliş: 25.11.2020

Kabul: 05.02.2021

Online Yayınlanma 30.06.2021

DOI: 10.29133 /yyutbd.831067

\section{Anahtar kelimeler}

Balık atığ 1 ,

Protein hidrolizat,

Enzimatik hidroliz.
Öz: Balık atıkları besinsel açıdan değerli, fonksiyonel özelliklere sahip ve kolay sindirilebilir, ekonomik değeri yüksek proteinli ürünlere dönüştürülebilirler. Balık işleme atıklarından kullanılabilir gıda ve biyoaktif bileşiklerin dönüşümü ile ilgili çalışmalara ve ticari üretime ağırlık verilmiştir. Balık protein hidrolizatları (BPH) ticari ürün olarak fonksiyonel gıda, hayvansal yem, organik gübre ve evcil hayvan gıdası olarak kullanıldığı gibi BPH' larının içerdikleri nutrasötik özellikteki biyoaktif peptitler ile antihipertensif, antitrombotik, antikanser, immunomodulatör ve antioksidan aktivitesi gösterdikleri için tıp ve farmakolji alanında da değerlendirilmektedir. Hidrolizatlarının besleyici özelliklerinin, diğer protein hidrolizatlarından daha dengeli ve üstün olduğunu göstermektedir. Protein hidrolizatı üretmek için kimyasal ve enzimatik olmak üzere iki farklı yöntem kullanılmaktadır. Son zamanlarda; daha düşük sıcaklık, basınç ve 5-8 arası bir $\mathrm{pH}$ aralığı kullanıldığı için enzimatik yöntemle hidrolizat üretimini daha cazip hale getirmiştir. Hidrolizasyonun en etkili göstergesi hidroliz derecesi $(H D(\%))$ olarak kullanılmıştır. Yapılan çalışmalardan elde edilen bulgulara göre, protein geri kazanımı için parçalanmış peptit bağlarının daha yüksek olması, $\mathrm{HD}(\%)$ ' nin yükselmesine neden olmaktadır. Küçük molekül ağırlığına sahip proteinlerin suda daha fazla çözünürlüğ̈̈, hidrolizatın protein geri kazanımını artırarak, fonksiyonel özelliklerini daha kullanılabilir hale getirmektedir. Araştırmalarda elde edilen farklı değerlerin balık türlerine, atık kompozisyonuna, enzim türüne, hidroliz yöntemine (sıcaklık, süre ve enzim oranı) göre değişebileceği görülmektedir. $\mathrm{Bu}$ araştırmada balık işleme atıklarından enzimatik hidroliz yöntemi kullanılarak balık protein hidrolizatı üretimi konusu derlenmiştir.

\section{Production of Fish Protein Hydrolizate Using Enzymatic Hydrolysis from Fish Processing Wastes}

\section{Article Info}

Received: 25.11.2020

Accepted: 05.02.2021

Online Published 30.06.2021

DOI: 10.29133/yyutbd.831067
Abstract: Fish waste can be transformed into nutritionally valuable, functional and easily digestible protein products with high economic value. Studies on the transformation of usable food and bioactive compounds from fish processing wastes and commercial production were focused. Fish protein hydrolyzates (FPH) are used as functional food, animal feed, organic fertilizer and pet food as commercial products, as well as in the field of medicine and pharmacology as they show antihypertensive, antithrombotic, anticancer, immunomodulatory and antioxidant activities with the nutraceutical properties they contain. It shows that 
Keywords

Fish waste,

Protein hydrolysate,

Enzymatic hydrolysis. the nutritional properties of fish hydrolyzates are more balanced and superior than other protein hydrolyzates. Two different methods, chemical and enzymatic, are used to produce protein hydrolyzate. Recently; It has made the production of hydrolyzate by enzymatic method more attractive as it uses lower temperature, pressure and a $\mathrm{pH}$ range of 5-8. The most effective indicator of hydrolysis was used as HD (\%). According to the findings obtained from the studies conducted, it has been determined that higher cleaved peptide bonds for protein recovery cause HD (\%) to increase. It has been reported that proteins with smaller molecular weights have greater solubility in water, thus increasing the protein recovery of the hydrolyzate and making its functional properties more useful. It is seen that the different values obtained in the studies may vary according to the fish species, waste process, enzyme type, hydrolysis method (temperature, time and enzyme ratio). In this study, the production of fish protein hydrolyzate from fish processing wastes by using enzymatic hydrolysis method was compiled.

\section{Giriș}

Dünyada artan nüfusun, protein ihtiyacının desteklenmesi için su ürünleri yetiştiriciliği en hızlı büyüyen gıda üretim sektörüdür (FAO, 2018).Ülkemizde balık atıklarının bir kısmından genellikle biyolojik değerliliği ve ekonomik değeri düşük balık unu elde edilmektedir. Geri kalanı da değerlendirilmeden kirlilik etmeni olarak çevreye atılmaktadır. Halbuki bu kaynaklar besinsel açıdan değerli, fonksiyonel özelliklere sahip ve kolay sindirilebilir, ekonomik değeri yüksek proteinli ürünlere dönüştürülebilirler (Ceylan, 2018; Uçar, 2020). Genel olarak, fileto olarak değerlendirilen balıkların \% 60-70' ini balık kafaları, deri, pul, kemik, iç organlar ve işlenemeyen et parçaları oluşturmaktadır. Avrupa Birliği, Altıncı Çevre Eylem Planı'nın dört önceliğinden biri olarak atık yönetimi belirlenmiş ve atığın kaynağında önlenmesinin yanı sıra geri dönüşümün teşvik edilmesi, kaçınılmaz olan atığın kaynak olarak kullanımı ve ek doğal kaynakların çıkarılması $A B$ atık yönetimi politikalarının ana unsurlarını teșkil etmiștir. Bu nedenle, bu ülkelerde balık işleme atıklarından kullanılabilir gıda ve biyoaktif bileşiklerin elde edilmesi ile ilgili çalışmalara ve ticari üretime ağırlık verilmiştir. Ülkemizde ise bu atıkların çok az bir kısmı hayvan yeminde kullanılmak üzere cuzi bir ücretle balık unu üreten fabrikalara satılmaktadır. Fakat buradan elde edilen balık ununun biyolojik değerliliği oldukça düşüktür. Geriye kalanı ise değerlendirilemeden direkt kirlilik unsuru olarak çevreye bırakılmaktadır. Balık protein hidrolizat üretimi (FPH) ile elde edilen hidrolizat geleneksel balık unu üretimi ile karşılaştırıldığında, birçok farklı amaçla kullanılabilecek özelliklere sahip bir ürün olarak katma değeri yüksek bir ürün haline dönüştürülür. Protein hidrolizi üretmek için kimyasal ve enzimatik olmak üzere iki farklı yöntem kullanılmaktadır. Kimyasal yöntemde, yüksek sıcaklık $\left(120^{\circ} \mathrm{C}\right)$ ve basınç $(100 \mathrm{kPa})$ altında asit veya alkali koşullar uygulanmaktadır. Bu yöntem daha ekonomik üretim maliyetine sebep olsa da hidrolizatta arzu edilen fonksiyonel özelliklerinin kaybolmasına ve ekipman korozyonuna sebep olduğu için son yıllarda çok tercih edilmemektedir. Enzimatik yöntemde ise, daha düşük sıcaklık, basınç ve 5-8 arası bir pH aralığı kullanıldığı için bu dezavantajların büyük bir çoğunluğu oluşmaz. Bu durum, son zamanlarda enzimatik yöntemle hidrolizat üretimini daha cazip hale getirmiştir (Diniz ve Martin, 1997; Sathivel ve ark., 2005; Slizyte ve ark., 2005). Yüksek katma değerli protein hidrolizatlarını (PH) üretmek için iyi tanımlanmış protein hidrolizatları enzimatik yöntemle üretilmiştir. Proteinler kolaylıkla, düşük sıcaklık ve pH koşullarında deaktive edilir. Balık ve atıklarından protein hidrolizatı üretmek için ticari olarak kullanılan birçok enzim bulunmaktadır. Bromelain (Aspmo ve ark., 2005) ve papain (Hoyle ve Merritt, 1994) gibi bitkisel kaynakl1, kimotripsin, tripsin (Simpson ve ark., 1998) ve pepsin (Viera ve ark., 1995) gibi hayvansal kaynaklı veya alkalaz, nötraz, flavourenzim, protameks ve proteaz $\mathrm{N}$ (Kristinsson ve Rasco, 2000a; Guèrard ve ark., 2001; Liaset ve ark., 2002) gibi mikrobiyolojik kaynakl1 enzimler balık protein hidrolizatının üretiminde kullanılmıştır. Enzimatik hidroliz, çeşitli enzimlerin kullanımı sayesinde, üreticinin en iyi ürünü elde etmesine olanak sağlamaktadır. Su ürünlerinden protein hidrolizatının ticari bir ürün haline dönüştürülebilmesi için değerlendirilemeyen ve avcılık yoluyla üretim miktarı yüksek olan türlerin tespitine yönelik çalışmaların yapılması gerekmektedir. Araştırma kapsamında ikincil verilerden yararlanılmış olup, balık atıklarının değerlendirilmesi, hidrolizat yöntemlerinin karşılaştırılması ve üretim aşamaları ile ilgili olarak bilimsel çalışmalar incelenmiş olup, literatüre katkı sağlaması ve farkındalık oluşturması amacıyla bu derleme çalışması hazırlanmıştır. 


\subsection{Balık atığı proteinleri}

Balık atıklarında önemli miktarda protein bulunduğu bildirilmektedir. Raghavan (2008), balık atığındaki protein miktarının balıktaki toplam proteinin \% 10-20'sine kadar (ağırlık/ağırlık) bulunabileceğini bildirmiştir. Balıktaki pullar ve deriye ek olarak balık kemiği çok iyi bir kolajen ve jelatin kaynağıdır. Balık ve kabuklu deniz hayvanları kas proteinleri sarkoplazmik, miyofibriler ve stroma proteinleri olmak üzere üç ana gruptan oluşur. Sarkoplazmik proteinler (su veya düşük tamponlu çözeltilerde çözülebilir), sarkoplazmada mevcut olan, yaklaşık olarak toplam kas dokusu proteininin \% 15-35'ini kapsar. Bu proteinler esasen enerji ile ilişkili kreatin kinaz, aldolaz, gliseraldehit ve 3 fosfat dehidrojenaz gibi enzimlerden oluşur. Türlere bağlı olarak miyoglobin ve hemoglobin gibi pigmentli proteinler suda çözünür protein sınıfinda bulunabilirler. Sarkoplazmik proteinlerin içeriği ve bileşimi türler arasında değişiklik gösterebilir. Örneğin bazı yumuşakçalarda hemoglobin yoktur. Ayrıca, balıklar ve memeli sarkoplazmik proteinleri arasında kompozisyon içerikleri bakımından da farklılıklar görülebileceği bildirilmiştir (Belitz ve ark., 2004). Örneğin balık miyoglobini sistein amino asitini içerirken, buna karşılık memeli myoglobini bu aminoasiti içermemektedir. Myofibriller proteinler, yüksek tuzlu çözeltilerde çözünen yapısal proteinlerdir. Bu proteinlerin oranı balık kaslarındaki toplam proteininin \% 65-75'ini kapsar. Yapısal proteinler içerisinde en çok orana sahip olan aktin ve miyosin, kasların kasılmasından sorumlu iki kas proteinidir. Miyosin yapısal proteinlerin \% 50 ile \% 58 arasında aktin ise \% 15-20 arasında kapsamaktadır. Miyosin iki ağır (223 kDa) ve iki hafif zincir (22 ve $18 \mathrm{kDa})$ içeren büyük bir moleküldür. Molekül hafif zincirleri içeren bölgeler ve ağır zincirlerin önemli bir kısmı iki tane aynı küresel kafa yapısına sahiptir. Kuyruklar, ağır zincirlerin çok uzun $\alpha$-heliks oluşturduğu birbirini saran sarmallar oluştururlar (Şekil 1A) (Blaber, 2001). Aktin iki şekilde oluşur: küresel monomer G-aktin ve miyosine bağlanan büyük bir polimer olan F-aktin dir. İnce filamentler kas kasılmasını düzenleyerek çok önemli bir rol oynar (Şekil 1B) (Anonim, 2006). Diğer kasılma ile ilişkili yapısal ve düzenleyici proteinler ve miyofibriler proteinleri, tropomiyosin, troponin, aktinin, desmin, nebülin ve $\mathrm{C}$ ve $\mathrm{M}$ proteinleridir.

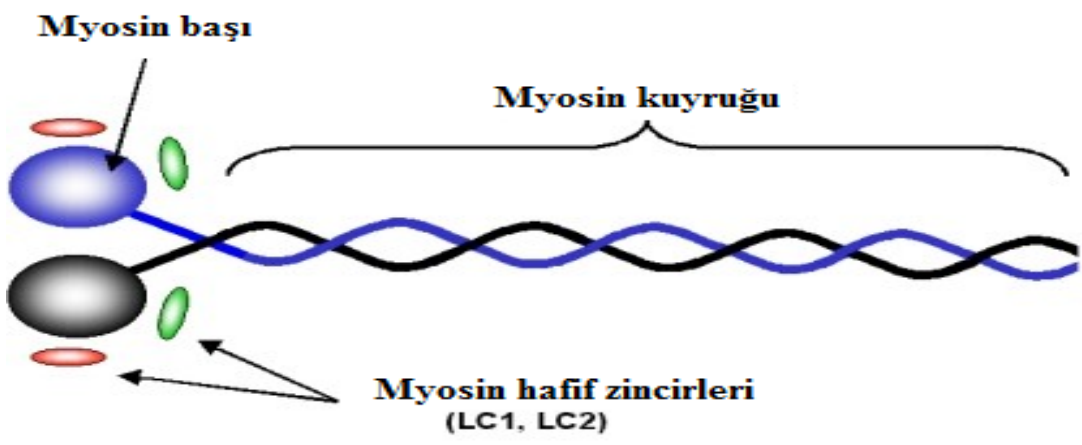

(A)

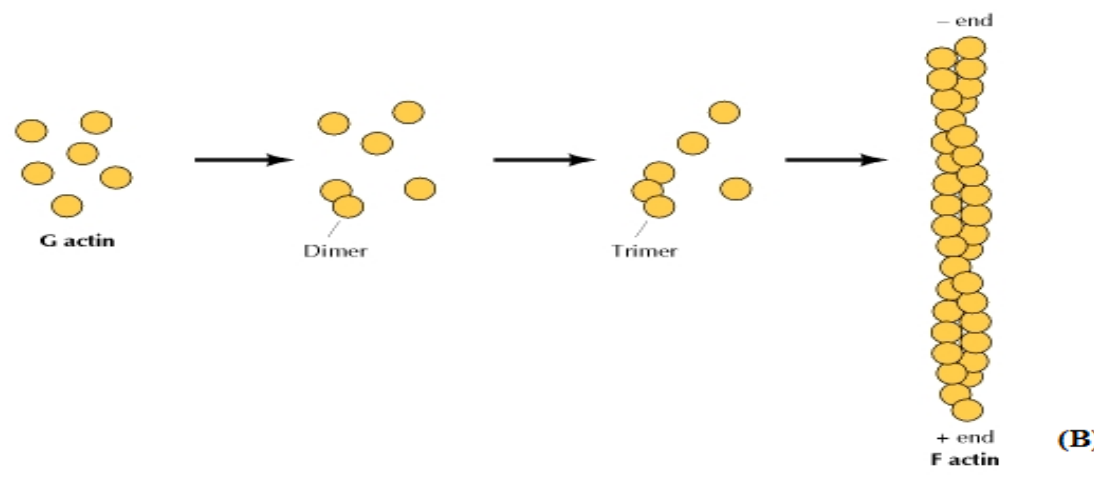

Şekil 1. (A) Myosinin ve (B) aktinin yapısal şekli.

Ağırlıklı olarak kolajen, geri kalan kısmı elastin ve jelatinden oluşan bağ dokusu veya stroma proteinleri, ortalama olarak toplam kas proteininin \% 3'ünü oluşturur. Balık derisi, kemikler ve pullardaki kollajen, kas dokuda da, önemli bir yapısal proteindir. Bu üçlü sarmal protein ve kısmen 
hidrolize edilen sargili form olan jelatin, polar olmayan glisin, valin, alanin, prolin ve hidroksiprolin amino asitleri açısından zengindir. Hidrofobik amino asitlerinden prolin, lipid peroksidasyonunun ve anjiyotensin dönüştürücü enzim (ACE)' in önlenmesinde önemli rol oynar.

\subsection{Balık protein hidrolizat üretimi}

Hidroliz, su kullanılarak iki molekül arasındaki bağlantının koptuğu bir işlemdir. Proteinler, hidrolize edilirken daha küçük peptitlere ve serbest amino asitlere hidroliz olurlar. Şekil 2'de bir dipeptitin iki serbest amino aside hidrolizi gösterilmiştir (Anonim, 2009). Hidroliz işlemine hammaddenin kompozisyonu, enzim tipi, su, endojen enzimlerin inaktivasyonu, $\mathrm{pH}$, sicaklik ve zamanın etkili olabileceği öne sürülmektedir (He ve ark., 2013).

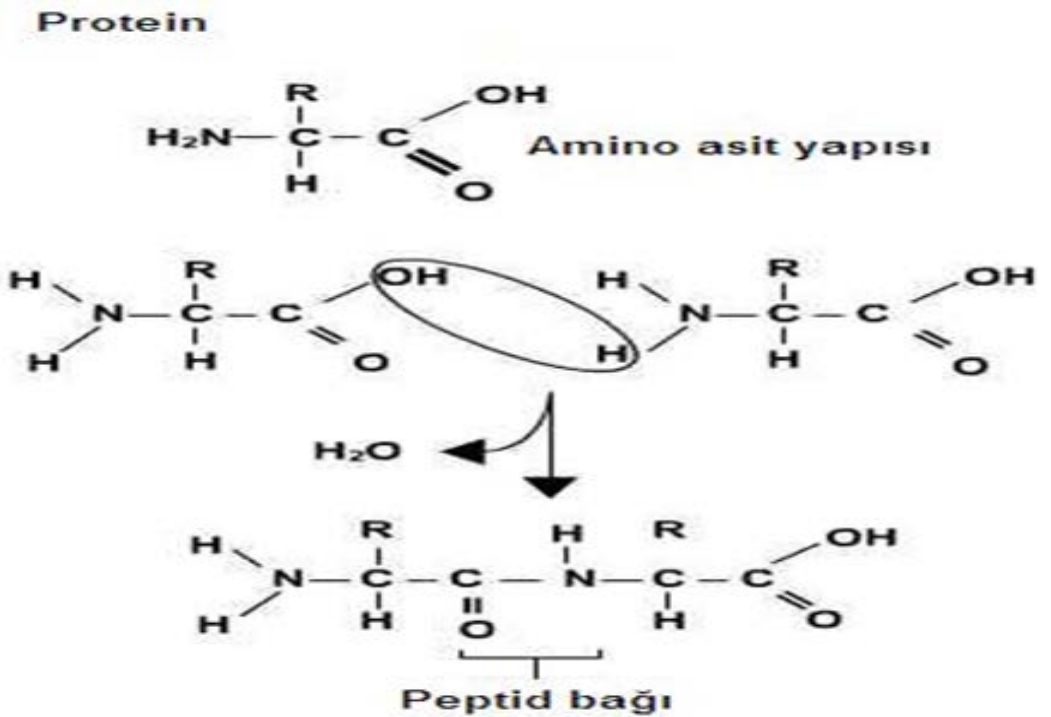

Şekil 2. Bir dipeptidin iki serbest aminoasite hidrolizi

Hidroliz hem kimyasal hem de enzimatik olarak gerçekleştirilebilir. Kimyasal hidroliz için asit veya baz kullanırken, enzimatik hidroliz enzimler tarafından katalizlenir. Kimyasal hidroliz, yüksek protein geri kazanımı, hızlı işleme ve düşük maliyet nedeniyle her ne kadar popüler olsa da, bahsedilen fizikokimyasal ve biyoaktif işlevselliklerinde zayıflığa neden olduğu için hidrolizat kalitesini kontrol etmek oldukça zordur. $\mathrm{Bu}$ dezavantajlar, kimyasal yöntemle elde edilen protein hidrolizatlarının yiyecek, içecek ve ilaç sektöründe kullanımını önemli derecede sınırlandırmaktadır. Günümüzde kimyasal yöntemle elde edilen hidrolizatlar, sadece gübre ya da laktik asit bakterilerinin gelişimi için azot kaynağı gibi düşük değerli ürünler için kullanılmaktadırlar. Öte yandan, enzimatik hidroliz ile karşılaştırıldığında süreci kontrol etmek genellikle zordur ve ayrıca aşırı $\mathrm{pH}$, basınç ve sıcaklık kullanıldığ 1 için besinsel kalite azalmakta ve tutarsız fonksiyonel özelliklere sebep olabilmektedir (Slizyte, 2004). Diğer dezavantajları ise; sindirimin ardından nötralizasyon için aşırı miktarda $\mathrm{NaCl}$ kullanımı, esansiyel aminoasit triptofanın tahribatı ve lezzet arttırıcılar olarak hidrolizatların kısıtlı kullanımına sebep olması sayılabilir (Hordur ve ark., 2000). Asit hidrolizi alkaliden daha popülerdir çünkü alkali hidroliz için kullanılan kimyasallar, çoğunlukla hidrolizin besleyici değerine ve fonksiyonel özelliklerine olumsuz etki ederler. Enzimatik yöntemde ise, daha düşük sıcaklık, basınç ve 5-8 arası bir pH aralığı kullanıldığı için bu dezavantajların büyük bir çoğunluğu oluşmaz. Bu durum, son zamanlarda enzimatik yöntemle hidrolizat üretimini daha cazip hale getirmiştir. Yüksek katma değerli protein hidrolizatlarını $(\mathrm{PH})$ üretmek için iyi tanımlanmış protein hidrolizatları enzimatik yöntemle üretilmiştir. Proteinler kolaylıkla hafif sıcaklık ve $\mathrm{pH}$ koşullarında deaktive edilir. Üreticinin arzu edilen nihai ürüne dayalı en iyi ürünü elde etmek için farklı kaynaklardan gelen çeşitli enzimlerin kullanımına olanak sağlanmaktadır (Pasupuleti ve Braun, 2010). Balık yan ürünlerinden aynı anda protein ve yağı elde etmek için enzimatik hidroliz kullanmıştır (de Oliveira ve ark., 2017). Enzimatik hidroliz, hidrolizin besinsel kalitesi ve fonksiyonel özellikleri bakımından daha iyi kaliteye sahip olduğu için gelecekte daha popüler olacağı düşünülmektedir. Enzimatik hidroliz ayrıca fizikokimyasal, 
fonksiyonel ve / veya duyusal özellikleri iyileştirmek veya değiştirmek içinde kullanılmaktadır. Sağlık için gerekli esansiyel ve esansiyel olmayan amino asitler FPH'de bol miktarda bulunmaktadır (Idowu ve ark., 2019). Balık protein hidrolizatlarının fonksiyonel özellikleri, protein kaynaklarına, kullanılan proteazlara, hidroliz derecesine, reaksiyonun süre ve sıcaklığına ve tampon pH'sına göre değişirken, duyusal özellikleri ise kullanılan proteolitik enzim türüne ve hidroliz reaksiyon koşullarının etkisine bağlı olarak değişmektedir. Bunlar içerisinde özellikle hidroliz derecesi, bir proteoliz değerlendirme parametresi olarak kullanılmaktadır ve farklı protein hidrolizatlarının karşılaştırılmasında da bir gösterge olarak değerlendirilmektedir. Çizelge 1'de kimyasal ve enzimatik hidrolizin karşılaştırılması verilmiştir. (Sanmartin ve ark., 2009).

Çizelge 1. Balık protein hidrolizatı üretiminde kimyasal ve enzimatik hidrolizin karşılaştırılması

\begin{tabular}{|c|c|c|}
\hline Hidrolizat Yöntemi & Avantajları & Dezavantajları \\
\hline $\begin{array}{l}\text { Kimyasal Yöntem } \\
\text { (asit ve alkali) }\end{array}$ & $\begin{array}{l}\text { Yüksek protein geri kazanım } \\
\text { Kısa işlem süresi } \\
\text { Düşük işleme maliyeti }\end{array}$ & $\begin{array}{l}\text { Acılık } \\
\text { Kötü fonksiyonel özellikler } \\
\text { Yüksek tuz içeriği } \\
\text { Metallerin metal aşındırması } \\
\text { Tepkimenin zor kontrolü } \\
\text { Lysino-alanin gibi toksik maddeler } \\
\text { oluşturması } \\
\text { İnsanlar vücudu tarafından emilmeyen D- } \\
\text { amino asitlerin oluşumu }\end{array}$ \\
\hline Enzimatik Yöntem & $\begin{array}{l}\text { Daha az acı hidrolizat üretimi } \\
\text { Fonksiyonların ve } \\
\text { Besleyici değerin korunması } \\
\text { Son üründe düşük tuz içeriği } \\
\text { Homojen hidrolizat üretimi }\end{array}$ & $\begin{array}{l}\text { Yüksek işleme maliyeti } \\
\text { Uzun işlem süresi }\end{array}$ \\
\hline
\end{tabular}

Benjakul ve Morrisey (1997), pasifik merlanının katı atık proteinleri için optimum hidrolize koşulların 9.5 pH, 60 derece hidroliz sıcaklığı, 60 dakika hidroliz süresi ve katı atık ve tampon karışımı için (1:1 w/v) 20 Alkalaz kg'lik enzim seviyesi olarak bulmuşlardır. Ayrıca hidrolizatların acılığını azaltabileceği ve alkalazın diğer proteazlara göre daha az acı hidrolizatlar ortaya çıkardığı da tespit edilmiştir

\subsection{Enzimatik hidroliz}

Enzimler, gıda endüstrisinde istenilen reaksiyonun katalizlenmesinde ve yüksek değerli ürünlere dönüştürülmesinde büyük oranlarda kullanılmaktadır . Proteolitik enzimler, ekonomik olarak en önemli enzim gruplarıdır . Proteolitik enzimlere proteazlar, proteinazlar ve peptitazlar da denir. Özelliklerine bağlı olarak proteolitik enzimler, değişen sekanslar ve uzunluklardaki peptitleri veren iki amino asit arasındaki peptit bağını koparırlar. Endopeptitazlar, peptit zincirindeki peptit bağlarını parçalayıp büyük peptitler üretirken, ekzopeptitazlar zincirin sonundaki peptit bağlarını parçalayarak dipeptitler ve serbest amino asitler oluştururlar. Enzimler, aynı zamanda aktif bağlantı bölgelerine göre de sinıflandırılabilirler. Örneğin sistein endopeptitazları, aktif bölgelerinde oldukça reaktif bir sistein kalıntısı içerirler (Neil ve ark., 2013). Proteinlerin enzimatik hidrolizi, zaten hammadde içinde mevcut olan endojen enzimlerle veya ticari enzimlerin eklenmesiyle gerçekleştirilebilir. Endojen enzimler, proteini çözündürmeye ve hidrolizatı arttırmaya yönelik ticari enzimlere göre daha fazla hidroliz işleminde verimli olabilirler. Karaciğer ve bağırsak gibi hammadde fraksiyonları yüksek endojen proteolitik aktiviteye sahiptirler. Endojen ve ticari enzimlerin eşzamanlı kullanımı, daha yüksek hidrolizat verimlerinde tek başına ticari enzim kullanmasından daha yüksek verim alınmasına sebep olabilirler. Bununla birlikte, ticari enzimlerin tek başına kullanılması, elde edilecek ürünün özelliklerini kontrol etmede daha etkili olacaktır. Kontrollü ve yeniden üretilebilir işlemler son derece önemlidir ve bu nedenle hammadde türüne göre endojen enzimler önce etkisiz hale getirilir ve ticari enzimlerin eklenmesi bundan sonra gerçekleştirilir. Proteazlar hayvan, bitki ve mikrobiyolojik kaynaklardan türetilmektedir. Bazı bitki kaynaklarından ekstrakte edilen enzimler arasına papain, bromelain ve keratinaz sayılabilir. Hayvanlardan ekstrakte edilen enzimler arasında ise tripsin, kimotripsin, pepsin ve 
renin sayılabilir. Bitki ve hayvan proteazlarının pazardaki mevcut talebi karşılayamaması nedeniyle, mikrobiyal proteazlara olan talebin artması da söz konusudur (Kristinsson ve Rasco, 2000). Bakteriyel proteazlar sıklıkla protein hidrolizatının üretiminde kullanılır. Bunlar esasen nötr veya alkalidir ve Bacillus cinsi bakteriler tarafindan üretilirler. Nötr proteazlar, 5-8 pH aralığında aktiftir ve düşük sıcaklık toleransına sahiptir. Alkali proteazlar, $7-10 \mathrm{pH}$ aralığında aktiftir ve geniş özgüllüğe sahiptir. Protein hidrolizatları üretmek için çok çeşitli ticari enzimler kullanılmıştır ve bunlar alkalaz (subtilisin), bromelain, kimotripsin, katapsin, Corolaz 7089, Korolaz PP, Denazyme AP, fisain (ficin), Flavourenzim, pankreatin, papain, pepsin, plazmin, Protameks R, Proteinaz K, Proteks 6L, Nötraz, Seabzyme, termolizin, tripsin ve birkaç diğer proteaz bitkilerden, mikroorganizmalardan ve hayvan dokularından türetilmiştir (Tveit, 2014). Alkalaz, deterjan endüstrisi için Novo Nordisk (Bagsvaerd, Danimarka) tarafından geliştirilen Bacillus licheniformis'den üretilen bir alkali enzimdir. Bu enzimin, balık protein hidrolizatını hazırlamak için kullanılan en iyi enzimlerden biri olduğu kanıtlanmıştır (Benjakul ve Morrissey, 1997). Shahidi ve ark. (1995), alkalaz tarafindan üretilen balık protein hidrolizatının daha iyi fonksiyonel özelliklere, çok iyi bir azot verimi ile yüksek bir protein içeriğine, kasın içerdiği amino asit kompozisyonuna benzer ve nötraz gibi diğer enzimlere kiyasla daha yüksek bir besleyici değere sahip olduğunu belirtmişlerdir. Çizelge 2' de balık protein hidrolizat üretiminde kullanılan ticari enzimlerin özellikleri verilmiştir (Vercruysse ve ark., 2005).

Çizelge 2. Balık protein hidrolizat üretiminde kullanılan enzimler

\begin{tabular}{lll}
\hline Enzimler & Orijini & \multicolumn{1}{c}{ Özgünlük } \\
\hline Alkalaz & Bacillus licheniformis & Dar, esas olarak hidrofobik aminoasitler için \\
\hline Nötraz & $\begin{array}{l}\text { Bacillus } \\
\text { amyloliquefaciens }\end{array}$ & Dar, başlıca Leu ve P için \\
\hline Papain & Papaya & Geniş, endoproteaz \\
\hline$\alpha$-Kemotripsin & Bovine pancreas & $\begin{array}{l}\text { Treonin, Triptofan, Fenilalanin, Lösin C- } \\
\text { terminalinde }\end{array}$ \\
\hline Flavourenzim & Aspergillus oryzae & Endoprotidaz ve Ekzoproteaz karışımı \\
\hline
\end{tabular}

\subsubsection{Enzimatik hidroliz üretim basamakları}

Enzimatik hidrolizle balık protein hidrolizatı üretiminde üç ana işlem basamağı kullanılmaktadır. Bunlar; ön hidrolizasyon, hidrolizasyon ve geri kazanım aşamasıdır. Şekil 3 de, enzimatik yöntemle balık protein hidrolizatı üretmek için kullanılan akış diyagramı gösterilmektedir (He ve ark., 2013). 


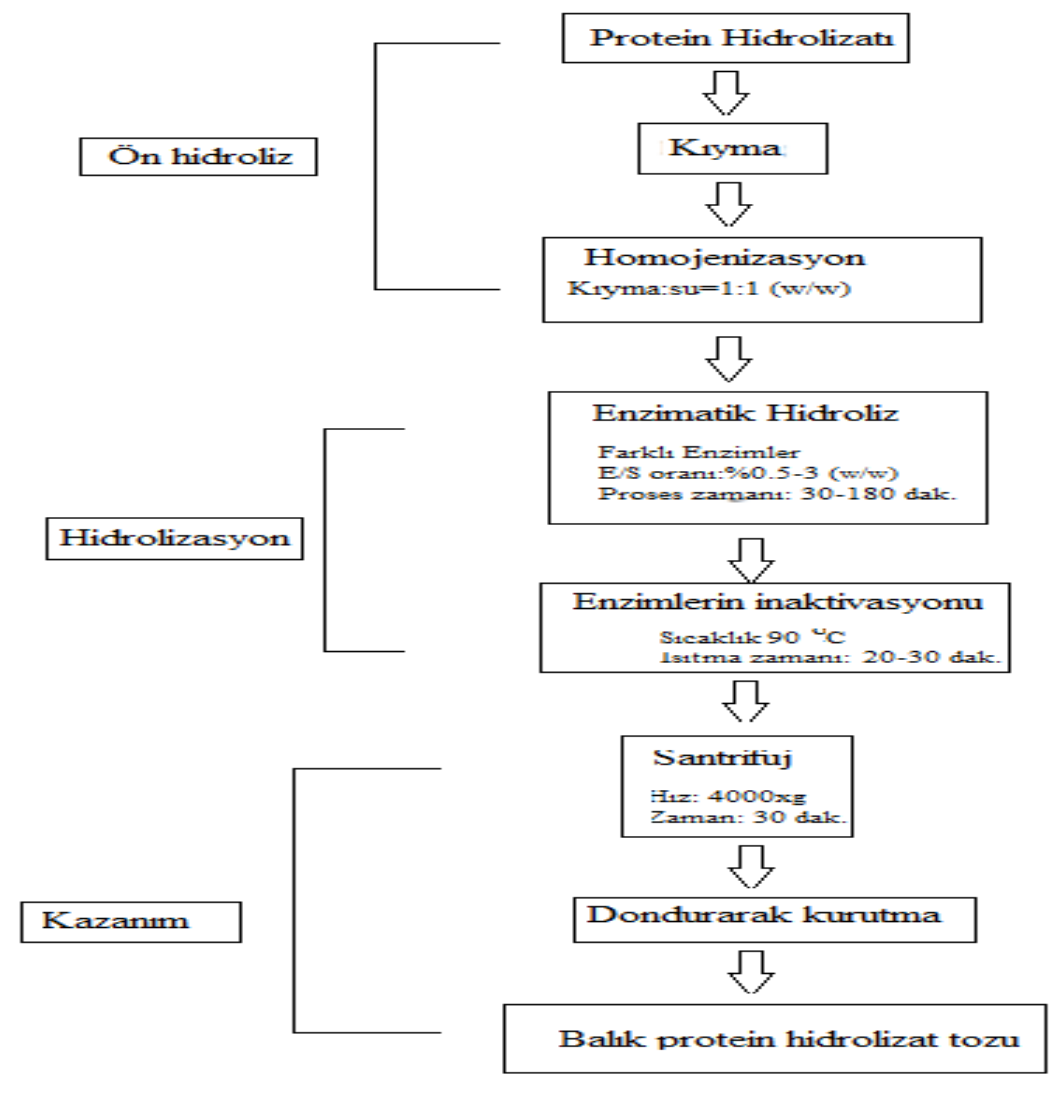

Şekil 3. Enzimatik yöntemle balık protein hidrolizatı üretmek için kullanılan akış diyagramı.

\subsection{2. Ön hidroliz}

Ön hidrolizasyon basamağının amacı, sonraki basamakta olan hidrolizasyon aşaması için homojen hale getirilmiş düşük yağ içeriğine sahip su-kıyma karışımları hazırlamaktır. Bu nedenle, hidroliz aşamasından önce ticari enzimler eklenmeden, kıyılmış hammadde su ile karıştırılır. Bu, enzimlerin substrata kolay erişmesini sağlar. Bu işlem sediman fazındaki çözünür bileşenlerin geri kazanımını sağlayarak hidrolizat verimini artırır ve proteinin artmasına neden olur. Slizyte ve ark., (2005), kullanılan enzim türünden daha ziyade fazla su eklemenin verimi daha iyi etkilediğini belirtmiştir. Bunun olumsuz tarafı, yağ veriminin düşmesi ve emülsiyonun artmasına neden olmasıdır. Bununla birlikte, ilave edilen su sonrasında, kurutma veya konsantre etmek gibi suyun uzaklaştırılması için ek işlemlerin yapılmasını zorunlu hale getirmektedir. Bu şekilde, hidroliz maliyeti hem endojen enzimlerin inaktivasyonuyla hem de su ve ticari enzimlerin eklenmesiyle artar ve bu faaliyetlerin gerekliliği, arzulanan ürünün kalitesiyle bağlantılı olarak belirlenmelidir. Benjakul ve Morrissey (1997) balık atıkları ögütüldükten sonra eşit miktarlarla (ağırlık/ağırlık) su ile karıştırılarak homojen bir sukıyma bulamacı elde etmişler ve ürüne daha fazla su eklemenin protein geri kazanımını arttırmadığını, ancak suyun azaltılmasının protein hidrolizatlarının su uçurma oranının azaltılmasına sebep olacağını öne sürmüşlerdir.

\subsubsection{Hidrolizasyon}

Hidrolizasyon için seçilen enzim, ön işlem basamağından sonra elde edilen sulu bulamaç içine homojen bir şekilde karıştırılır. İşleme sıcaklığı ve $\mathrm{pH}$, seçilen enzimin en uygun değerlerine göre ayarlanır. Hidroliz, yaklaşık 30 dakika süre ile enzimleri $90^{\circ} \mathrm{C}$ 'de inaktif ederek son bulur.

Pepsin gibi $\mathrm{pH}$ değeri asidik olan enzimler düşük $\mathrm{pH}$ da mikrobiyal büyümeyi engelleyebilir. Ancak asidik pH atmosferi aşırı hidrolizasyona sebep olduğu için proteinin geri kazanımının düşük olmasına, triptofan amino asitinin yıkımına, zayıf fonksiyonel özelliklere ve besinsel kalitenin düşük olmasına yol açarlar (Kristinsson ve Rasco, 2000). Bu nedenle, optimum nötr seviyeye yakın pH 
değerine reaksiyona sahip enzimler olan alkalaz, nötraz ve flavourenzim günümüzde daha kapsamlı olarak kullanılmaktadır. Hayvansal veya bitkisel kökenli enzimlere kıyasla, mikrobiyal enzimler daha avantajlıdır. Teknik ve ekonomik açıdan bakıldığında, mikrobiyal enzimler örneğin alkalazın, balık proteinlerinden hidrolizat üretiminde alkali pH'da çalışan en verimli enzim olduğu bildirilmiştir. Enzimler ve protein hidrolizatlarının fonksiyonları arasındaki etkileşimin ayrıca balık türlerine göre değiştiği saptanmıştır (Herpvei ve ark., 2011).

\subsection{Hidroliz derecesi (\%HD) tespiti}

HD (\%), peptit bağlarının proteinden ayrıştığını gösteren bir indikatör olarak değerlendirilir (Benjakul ve Morrissey, 1997). Hidroliz işleminin etkinliğini gösteren hidroliz derecesi (HD), peptit bağlarının parçalanma yüzdesi olarak tanımlanmıştır. Şimdiye kadar hidrolizasyonun en etkili göstergesi HD (\%) olarak kullanılmıştır. Yapılan çalışmalardan elde edilen bulgulara göre, protein geri kazanımı için parçalanmış peptit bağlarının daha yüksek olması, HD (\%)' nin yükselmesine neden olduğu saptanmıştır. Daha küçük molekül ağırlığına sahip proteinlerin suda daha fazla çözünürlüğü, böylece hidrolizatın protein geri kazanımının artarak fonksiyonel özelliklerini daha kullanılır hale getirdiği bildirilmiştir. Kısaca yapılan çalışmalar, hidrolizatların fonksiyonel özellikleri ile HD (\%) arasında bir korelasyon oluşturduğunu göstermiştir (Shahidi ve ark., 1995). Hinsui ve ark. (2016), Skipjack tuna içorganlarının HD' sini (\% 61.73) Yellowfin tuna'nın içorganlarından elde edilen hidrolizatın HD' sinden (\% 52.98) yüksek tespit etmişlerdir. Baharuddin ve ark. (2016), alkalaz enzimi ile yapılan yılan balığ protein hidrolizatının hidroliz derecesi (HD \%) sonuçlarını hidroliz sürelerine bağlı olarak 120 dakikada \% 36, 180 dakikada \% 48, 300 dakikada \% 69 HD değerlerini tespit etmişlerdir. Ovissipour ve ark. (2012), alkalaz, protameks, nötraz, flavourenzim ve tripsin 5 farklı enzim kullanarak Pers mersin balığı için elde edilen en yüksek HD (\%) alkalaz hidrolizatlarında ve en düşük ise tripsin hidrolizatlarında tespit edilmiştir.

Yoon ve ark. (2015), Onchorhynchus keta ve Onchorhynchus gorbuscha karaciğer ekstraktını, piyasada bulunan dört farklı ticari enzimi kullanarak 1 saat hidroliz etmişlerdir. Protameks / alkalaz kompleksiyle elde edilen HD (\%)'ler $O$. keta ve $O$. gorbuscha için sırasıyla \% 21.7 ve \% 23.4 olarak bulunmuştur. HD değerleri, diğer proteolitik enzimler için \% 20 'den daha düşük elde edilmiştir. Enzimler olmadan, HD (\%) değerleri \% 8.9-10.5 aralığında bulunmuştur. Enzim tipi ve hidroliz koşulları son ürün verimi üzerinde belirgin etkilere sahiptir. Elde edilen çözünür proteinin en yüksek geri kazanımları, alkalaz kullanılarak $50^{\circ} \mathrm{C}^{\prime}$ de hidroliz ile $\mathrm{pH}$ 7.0' de elde edilmiştir (Çizelge 3).

Çizelge 3. Onchorhynchus keta ve Onchorhynchus gorbuscha'dan elde edilen protein hidrolizatlarının (\%HD)

\begin{tabular}{lllllll}
\hline & Kontrol & Flavourenzim & Protameks & Nötraz & Alkalaz & Protameks+Alkalaz \\
\hline O.keta & 10.5 & 13.2 & 14.4 & 15.8 & 14.8 & 21.7 \\
\hline O.gorbuscha & 8.9 & 15.7 & 17.1 & 17.5 & 18.5 & 23.4 \\
\hline
\end{tabular}

Baharuddin ve ark. (2016), yılanbalığı protein hidrolizatının (EPH) farklı hidroliz derecesinin (HD) etkisini araştırmışlardır. Hidroliz için, Bacillus licheniformis suşundan elde edilen bakteriyel bir endoproteinaz olan alkalaz kullanılmıştır $(2.4 \mathrm{Au} / \mathrm{g}$ ve yoğunluk $1.18 \mathrm{~g} / \mathrm{ml})$. EPH'nin alkalaz ile hidrolizi sırasıyla 120, 180 ve 300 dakika hidroliz zamanı için \% 36, \% 48 ve \% 69 hidroliz derecesine neden olduğu bulunmuştur. Koç (2016), hamsi (Engraulis encrasicolus) eti ve işleme atıklarını Alkalaz enzimi kullanarak üç farklı sürede $(60,120$ ve 180 dakika) protein hidrolizine tabi tutmuş; elde edilen hidrolizatların besleyici, fonksiyonel ve biyoaktif özelliklerini incelemiştir. Hamsi eti hidroliz

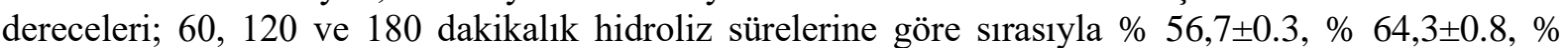
$67,3 \pm 0,7$ olarak tespit edilirken, atı örneklerinde bu değerler $\% 73,5 \pm 0.7, \% 78.0 \pm 0.7$ ve $\% 79.9 \pm 0.7$ şeklinde ve daha yüksek bulunmuştur. Araştırıcı, hidroliz derecesi özelliği üzerine materyal tipi ve hidroliz süreleri arasında önemli derecede $(\mathrm{p}<0.05)$ interaksiyon olduğunu tespit etmiştir (Şekil 4). 


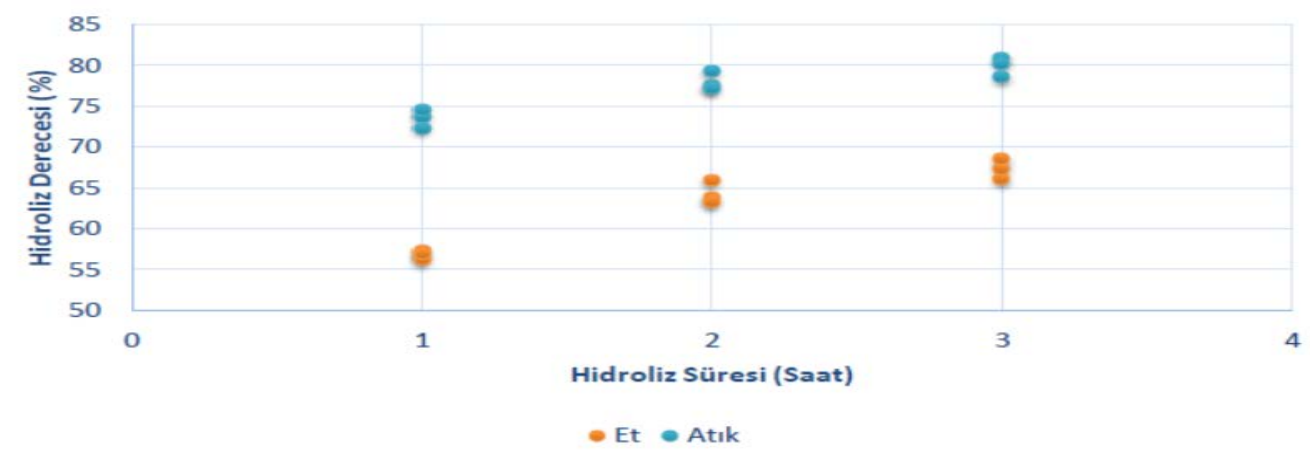

Şekil 4. Hidrolizatların hidroliz süreleri bazında hidroliz dereceleri (\%).

Korkmaz (2018), farklı enzimlerle 1,4.5 ve 8 saat hidrolize olan alabalık, hamsi ve mezgit atıklarından elde edilen protein hidrolizatlarının hidroliz dereceleri (\% HD) benzer şekilde bu çalışmada da, balık atığ 1 ve enzim türüne göre hidroliz derecesinin \% 50.92 ile \% 74.30 arasında değiştiği belirlenmiştir. Gruplar içinde en yüksek (HD\%) \% 74.30 ile alabalık atığının protameks ile hidrolizatından elde edilirken ( $\mathrm{p}<0.05)$, en düşük (HD\%) \% 50.92 ile mezgit atığının flavourenzim ile hidrolizinden elde edilmiştir. Hamsi atığ hidrolizatında ise en yüksek (HD\%) \% 68.23 ile flavourenzim ile elde edilmiştir.

\subsection{Protein geri kazanımı}

Protein geri kazanımı, hidroliz sonrası protein fazında bulunan proteinler ile hammadde de çözünür halde bulunan toplam proteinlerin yüzdesini gösterir. Hidrolizasyonun üretim basamağının son aşamasında, protein hidrolizatları toz haline getirilir. Balık protein hidrolizatlarının sıvı formları yüksek su içeriğine sahip olduğundan bakterilerin kolayca çoğalmasına olanak sağlarlar ve bu nedenle çabuk bozulabilirler. Balık protein hidrolizatlarının toz hali, taşıması daha hafif ve kolay olması açısından sıvı formdan daha uzun süre saklanabilirler. Geri kazanım için sıvı hidrolizat solüsyonu 20 dakika boyunca 4000 g'de santrifüj edilerek dört faza ayrılır: üstte yağ tabakası, hemen altında hafif protein lipit tabakası ortasında hidrolizat solüsyonu ve altta bir yarı katı katman bulunmaktadır (He ve ark. 2003). Balık atıklarından enzimatik hidroliz işlemi sonucunda yem hammaddesi, gıda katkısı ve takviyesi, sıvı organik gübre, balık yağı ve hidroksiapatit gibi katma değeri yüksek ürünler elde edilebilir. Şekil 5' de sıvı protein hidrolizatı elde edildiğinde ortaya çıkan fazlar gösterilmiştir (Korkmaz, 2018).

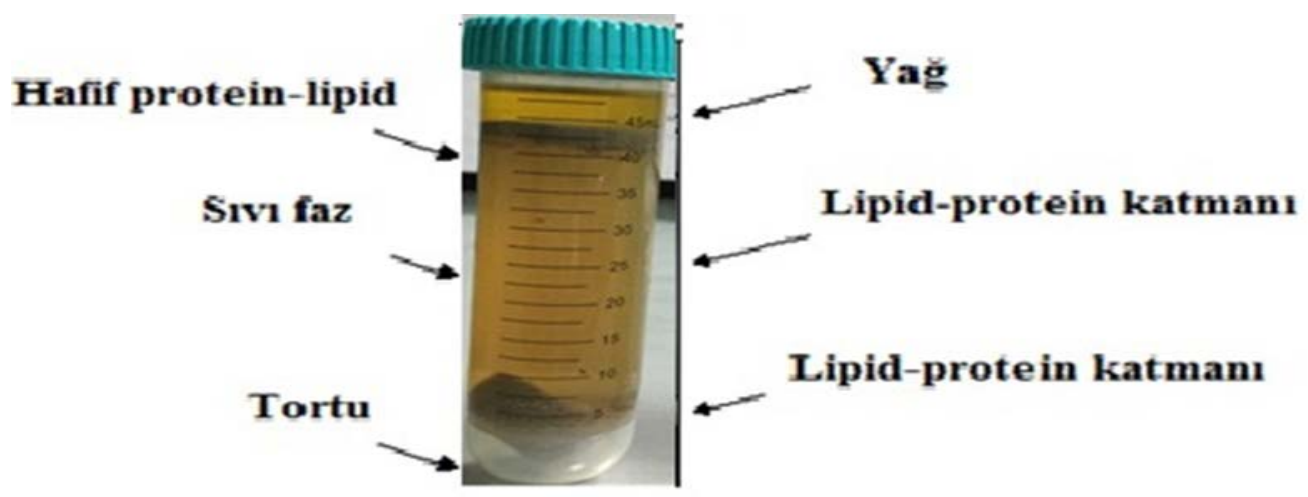

Şekil 5. Sıvı protein hidrolizat üretiminde ortaya çıkan fazlar (Korkmaz, 2018).

Shahidi ve ark. (1995), alkalaz, nötraz ve papain kullanılarak kapelin (Mallotus villosus)' den protein hidrolizatının ekstraksiyonu üzerine araştırma yapmışlardır. Ekstraksiyon solüsyonu ayrıca otolitik hidrolize tabi tutulmuştur. Elde edilen sonuçlar, otolitik hidroliz verimi ile karşılaştırıldığında ticari enzimlerle elde edilen protein geri kazanımlarının \% 22.9, \% 51.6, \% 70'e ulaştığını ortaya koymuştur. Alkalaz hidrolizi, diğer enzimlere kıyasla en yüksek protein geri kazanımını göstermiştir. 
Protein geri kazanımı, hidroliz sonrası protein fazında bulunan proteinler ile hammaddede çözünür halde bulunan toplam proteinlerin yüzdesini gösterir. Ovissipour ve ark. (2009) tarafindan, Pers mersin balığı için 5 farklı enzim (alkalaz, protameks, nötraz, flavourenzim ve tripsin) kullanılarak yapılan hidroliz çalışmasında, alkalaz ile hidroliz edilen balık proteininin 18 saat sonra en yüksek protein geri kazanımına (\% 83.64) sahip olduğunu göstermiştir. Araştırıcılar, Pers mersin balığı için alkalaz enzimini kullanarak protein verimini belirlemede zaman ve sıcaklığın önemli bir rol oynadığını bildirmişlerdir. Meldstad (2015), Atlantik morina (Gadus morhua) kafasından elde edilen protein hidrolizatı ile ilgili çalışmasında, en yüksek protein içeriğinin \% 88.4 ile taze morinadan üretilen hidrolizatlatlarda (FPH) elde edildiği, en düşük protein kazamının ise \% 67.7 ile dışarıda çözdürülmüş örneklerde olduğu görülmüştür. Korkmaz (2018), Alkali proteaz, protameks ve flavourenzim kullanılarak alabalık, mezgit ve hamsi atığı hidrolizatlarının protein geri kazanımları (\%) en yüksek protein geri kazanımı mezgit ve hamsi atığının protameks ile ve mezgit atığının alkali proteaz ile hidrolizatından elde edilirken ( $<<0.05)$, en düşük protein geri kazanımı \% 73.54 ile mezgit atı̆̆ının flavourenzim ile hidrolizinden elde edilmiştir $(p<0.05)$. Alabalık atığında en yüksek protein geri kazanımı \% 89.03 ile alkali proteaz ile tespit edilirken $(\mathrm{p}<0.05)$, bunu protameks ve flavourenzim takip etmiştir $(\mathrm{p}<0.05)$. Mezgit atığında en yüksek protein geri kazanımı \% 95.27 alkali proteaz ve \% 95.76 protameks ile saptanırken ( $\mathrm{p}>0.05)$, en düşük protein geri kazanımı \% 73.54 flavourenzim ile elde edilmiştir $(\mathrm{p}<0.05)$. Hamsi atığı hidrolizatında ise en yüksek protein geri kazanımı $\% 95.73$ ile protameks ile elde edilmiştir.

Araştırmalarda elde edilen farklı değerlerin balık türlerine, atık kompozisyonuna, enzim türüne, hidroliz yöntemine (sıcaklık, süre ve enzim oranı) göre değişebileceği görülmektedir.

\section{Sonuç ve Öneriler}

Atığın kaynağında önlenmesinin yanı sıra geri dönüşümün teşvik edilmesi, atığın kaynak olarak kullanımı ve ek doğal kaynakların çıkarılması gerekmektedir. Su ürünleri atıkları kirlilik unsuru olmaktan ziyade yüksek potansiyele sahip geri dönüşüm kaynaklarıdır. Balık atıklarından protein hidrolizatı üretiminde, atığın besin komposizyonunun mevsimsel değişiminin gözönüne alınması gerektiği düşünülmektedir. Su ürünlerinden protein hidrolizatının ticari bir ürün haline dönüştürülebilmesi için değerlendirilemeyen ve avcılık yoluyla üretim miktarı yüksek olan türlerin tespitine yönelik çalışmaların yapılması gerekmektedir. Balık atıklarının enzimatik hidrolizinde alkalin proteaz enziminin fiyat/fayda bakımından fizibilite raporunun araştırılması ve hidrolizat üretiminde önemli bir basamak olan kurutma, ürün kalitesinin korunması amacıyla çoğunlukla liyofilizasyon ile gerçekleştirilmekte, bu durum zaman ve maliyet açısından sıkıntı yaratmaktadır. Bu nedenle kurutma işleminde liyofilizasyonla kalite açısından rekabet edecek, daha hızlı ve düşük maliyetli yöntemlerin araştırılması önerilmektedir.

\section{Kaynakça}

Anonim. (2006). Miyosin ve aktinin yapısal şekli. http://educationportal.com/cimages/multimages/16/actin_filament.PNG- Erişim tarihi: 20.12.2017.

Anonim. (2009). Proteinler. www.lisebiyoloji.com/protein.html- Erişim tarihi: 20.12.2017.

Aspmo, S.I., Horn, S.J, \& Eijsink, V.G.H. (2005). Growth of Lactobacillus plantarum in media containing hydrolysates of fish viscera. Journal of Applied Microbiology 99, 1082-1089.

Baharuddin, N.A., Halim, N.R.A., Sarbon, N. M. 2016. Effect of degree of hydrolysis (DH) on the functional properties and angiotensin I-converting enzyme (ACE) inhibitory activity of eel (Monopterus Sp.) protein hydrolysate. International Food Research Journal, in press.

Belitz, H. D., Grosch, W., \& Schieberle, P. (2004). Fish, wales, crustaceans, mollusks. Food chemistry. Berlin, Heidelberg:Springer, 619-642.

Benjakul, S., \& Morrissey, M. T. (1997). Protein hydrolysates from Pacific whiting solidwastes. Journal of Agricultural ve Food Chemistry, 45(9), 3423-3430.

Blaber, M. (2001). Skeletal Muscle Myosin and Muscle Contraction http://www.mikeblaber.org/oldwine/BCH4053/Lecture31/Lecture31.htm-_Erişim tarihi: 20.12.2017. 
Ceylan, Z. (2018). Farklı günlerde soğuk muhafazadan çıkarılan ve farklı sıcaklıklarda pişirilen balıkların bazı kalite parametrelerinin incelenmesi. Yüzüncü Yıl Üniversitesi Tarım Bilimleri Dergisi, 28(3), 317-324.

de Oliveira, D.A.S.B., Licodiedoff, S., Furigo, A., Ninow, J.L., Bork,J.A., Podestá, R., Block, J.M., \& Waszczynskyj, N. (2017). Enzymaticextraction of oil from yellowfin tuna (Thunnus albacares) by-products: a comparison with other extraction methods. Int.J. Food Sci. Technol. 52.

Diniz, F. M., \& Martin, A.M. (1997). Effects of the Extent of Enzymatic Hydrolysis on Functional Properties of Shark Protein Hydrolysate. Lebensm. Wiss. U. Technol., 30, 266-272.

Food and Agriculture Organization. (2018) The State of Food and Agriculture 2018 Migration, Agriculture and Rural Development. Rome. Licence: CC BY-NC-SA 3.0 IGO.

Guerard, F., Dufosse, D., De La Broise, D., \& Binet, A. (2001). Enzymatic Hydrolysis of Proteins from Yellowfin Tuna (Thunnus albacares) Wastes Using Alkalaz. Journal of Molecular Catalysis B: Enzymatic, 11, 1051-1059.

He, S., Franco, C., \& Zhang, W. (2013). Functions, Applications ve Production of Protein Hydrolysates from Fish Processing Co-Products (FPCP). Food Research International, 50, $289-297$.

Herpvei, N. H., Rosma, A., \& Wan Nadiah, W.A. (2011). The Tuna Fishing Industry: A New Outlook on Fish Protein Hydrolysates. Comprehensive Reviews in Food Science and Food Safety, 11, 195-207.

Hinsui, J., Detkamhaeng, N., \& Worawattanamateekul, W. (2016). Production of protein hydrolysate from yellowfin (Thunnus albacares) and skipjack tuna (Katsuwonous pelamis) viscera. Kasetsart University Fisheries Research Bulletin, 40(2), 51-67.

Hoyle, N.T., \& Merritt, J.H. (1994). Quality of Fish Protein Hydrolysates from Herring (Clupea harengus). Journal of Food Science, 59 (1), 76-79.

Hordur, G., Kristinsson, B., \& Rasco, A. (2000). Fish protein hydrolysates:production, biochemical ve functional properties. Food Science ve Nutrition, 40(1), 43-81.

Idowu, AT., Benjakul, S., Sinthusamran, S., Sookchoo, P., \& Kishimura, H. (2019) Protein hydrolysate from salmon frames: Production,characteristics and antioxidative activity. Journal of Food Biochemistry 43, e12734.

Koç, S. (2016). Hamsi (Engraulis encrasicolus) ve işleme atıklarından elde edilen protein hidrolizatlarının besleyici, fonksiyonel ve biyoaktif özelliklerinin araştırllması, Doktora Tezi, Ç.O.M.Ü Fen Bilimleri Enstitüsü, Çanakkale.

Korkmaz, K. (2018). Ticari enzimler kullanılarak farklı balık Türü atıklarından hidrolizat üretimi ve Kalitesinin belirlenmesi, Doktora Tezi, O.D.Ü Fen Bilimleri Enstitüsü, Ordu.

Kristinsson, H.G., \& Rasco, B.A. (2000a). Biochemical ve Functional Properties of Atlantic Salmon (Salmo salar) Muscle Proteins Hydrolyzed with Various Alkalie Proteases. J. Agric. Food Chem., 48, 657-666.

Liaset, B., Nortvedt, R., Lied, E., \& Espe, M. (2002). Studies on the nitrogen recovery in enzymic hydrolysis of Atlantic salmon (Salmo salar, L.) frames by Protamex protease. Process Biochem., 37, 1263-9.

Meldstad, F. (2015). Hydrolysis of Marine Cod (Gadus Morhua) Head-Utilization of rest raw material from cod for production of ingredients for human consumption. Master's thesis, NTNU.

Neil, D., \& Guy, S. (2013). Handbook of Proteolytic Enzymes, volume 2. Amsterdam: Elsevier Academic Press, 3rd edition.

Ovissipour, M., Abedian, A. M., Motamedzadegan, A., Rasco, B., Safari, R., \& Shahiri, H. (2009a). The effect of enzymatic hydrolysis time and temperature on the properties of protein hydrolysates from the Persian sturgeon (Acipenser persicus) viscera. Food Chemistry, 115, 238-242.

Ovissipour, M., Safari, R., Motamedzadegan, A., Regenstein, J. M., Gildberg, A., \& Rasco, B. (2012). Use of hydrolysates from Yellowfin tuna (Thunnus albacares) heads as a complex nitrogen source for lactic acid bacteria. Food and Bioprocess Technology, 5, 73-79.

Pasupuleti, V. K., \& Braun, S. (2010). State of the art manufacturing of protein hydrolysates. Protein Hydrolysates in Biotechnology, 11-32.

Raghavan, S., \& Kristinsson, H.G. (2008). Antioxidative efficacy of alkali-treated tilapia protein hydrolysates: A comparative study of five enzymes. Journal of Agricultural and Food Chemistry, 56 (4), 1434-1441. 
Sanmartin, E., Arboleya, J. C., Villamiel, M., \& Moreno, J. (2009). Recent advances in the recoveryve improvement of functional proteins from fish processing by-products: Use of protein glycation as an alternative method. Comprehensive Reviews in Food Scienceve Food Safety, 8(4), 332 344.

Sathivel, S., Smiley, S., Prinyawiwatkul, W., \& Bechtel, P. J. (2005). Functional and nutritional properties of red salmon (Oncorhynchus nerka) enzymatic hydrolysates. Journal of Food Science, 70(6), 401-406.

Shahidi, F., Han, X.Q., \& Synowiecki, J. (1995). Production ve Characteristics of Protein Hydrolysates from Capelin (Mallotus villosus). Food Chemistry, 53, 285-293.

Simpson, B. K., Nayeri, G., Yaylayan, V., \& Ashie, N. A. (1998). Enzymatic hydrolysis of shrimp meat. Food Chemistry, 61(1/2), 131-138.

Slizyte, R. (2004). Hydrolysis of cod (Gadus morhua) by-products: Influenceof raw material composition ve process conditions. PhD thesis, NTNU,Faculty of Natural Sciences ve Technology, Department of Biotechnology.

Slizyte, R., Daukšas, E., Falch, E., Storro, I., \& Rustad,T. (2005).Yield and composition of different fractions obtained after enzymatic hydrolysis of cod (Gadus morhua) by-products. Process Biochemistry, 40, 1415-1424.

Tveit, G. M. (2014). Enzymatic hydrolysis of chicken rest raw material. Master's thesis, NTNU, Department of Biotechnology.

Uçar, Y. (2020). Su ürünlerinde nisin uygulamaları. Yüzüncü Yıl Üniversitesi Tarım Bilimleri Dergisi, 30 (3), 639-651.

Vercruysse, L., Camp, J. V., \& Smagghe, G. (2005). ACE inhibitory peptites derived from enzymatic hydrolysates of animal muscle protein: A review. Journal of Agriculture and Food Chemistry, 53(21), 8106-8115.

Viera, G. H. F., Martin, A. M., Sampaiao, S. S., Omar, S., \& Gonsalves, R. C. F. (1995). Studies on the enzymatic hydrolysis of Brazilian lobster (Panulirus spp.) processing wastes. Journal of Food Science and Agriculture, 69, 61-65.

Yoon, S., Watanabe, E., Ueno, H., \& Kishi, M.J. (2015). Potential habitat for chum salmon (Oncorhynchus keta) in the Western Arctic based on a bioenergetics model coupled with a threedimensional lower trophic ecosystem model. Prog. Oceanogr. 131, 146-158. 